\title{
Archaeologists riven by ban on South Africans
}

Preparations for the world congress on archaeology due to be held next September at Southampton, England, have been clouded by a ban on attendance by scientists from South Africa. Some of those now disinvited are complaining that the ban is an infringement of the rules of the Union Internationale des Sciences Préhistorique et Protohistorique (IUPPS) under whose aegis the congress is planned and whose constitution says that the union's proceedings shall be open to all. And some of those not affected by the ban who had planned to travel to Southampton next year have written to say that they will not now be attending.

Professor Phillip V. Tobias, professor of anatomy at the University of Witswatersrand and one of those affected by the ban, said at the weekend that the ban on the attendance of people from South Africa is the first to his knowledge to have been formulated by academics and enforced against fellow-academics. Usually, he said, obstacles to attendance at international conferences are decreed by governments, although there is now a long list of conferences from which people have withdrawn because they object to the presence of certain others.

The row at Southampton seems to have been forced on the local organizing committee by four separate though not necessarily independent pressures. The local university branch of the Association of University Teachers (AUT) seems to have taken the initiative, telling the organizing committee for the congress that national AUT policy forbids academics who are members of the union from maintaining links with South African academics. The students' union at Southampton, which controls some of the accommodation that the congress planned to use, followed with a threat of direct action. The AntiApartheid Movement had also written to more than a score of London embassies. asking them to boycott the congress.

Finally, the Southampton City Council, now under the control of the Labour Party, having expressed misgivings about the possible presence of South African scientists in Southampton next September, formally resolved last month to rid itself of all economic, academic and cultural links with South Africa. This decision appears to have been especially influential in guiding the organizing committee to its decision that membership of the congress should not be extended to those working in South Africa; the city council had earlier agreed to contribute towards the cost of the congress $£ 40,000$ in cash together with an unquantified amount of help with

\section{accommodation and hospitality.}

The members of the organizing committee seem to have found this summer's dilemma a painful experience. The chairman of the committee, Professor John Evans of the Institute of Archaeology at the University of London, explained this week that he and his fellow members had reached their decision reluctantly and in the belief that, without a ban, the congress would not be held. In reply to Tobias's complaint that the local organizing committee should not have taken a decision to ban South Africans without the agreement of the parent body, Evans said that the local committee had financial and operating responsibility only for next year's congress, but that IUPPS had no funds that might be used to meet the expenses already incurred in the preparations for the congress. He said that those who had announced their intention not to participate would be much missed, but hoped that many of them would change their minds nearer the time, and when they have been given a full explanation of the background.

At least some of the difficulties about the Southampton congress have arisen because of the scale on which it has been planned. The organizers appear to hope

\section{Meanness spells end}

The chances are now high that the Royal Greenwich Observatory will cease to contribute to the international determination of time later in the year. This is yet another unplanned consequence of the reduction of funds available to British research councils by the continuing application of the government's rigorous cash limits.

The difficulties at Greenwich (which, now, is actually placed at Herstmonceux in Sussex) have arisen because of the decision of the Science and Engineering Research Council (SERC) to concentrate support for astronomy on the observational facilities now available, especially at the observatory at La Palma in mid-Atlantic. The Royal Greenwich Observatory has for several months been primarily a means by which the La Palma operation may be supported, with on-site observation reduced to a minimum. The future of the observatory as an independent organization should be resolved when a further report on the subject is available later in the year.

Hitherto, the Greenwich contribution to the international time service provided by the International Bureau de l'Heure in Paris has been sustained by six atomic clocks, for which no further maintenance that it will be the largest ever, with participation from a number of developing countries that have not attended previous congresses (held at intervals of five years). It is planned that some sessions of the congress will be held in London. Four insurance companies have provided a bank guarantee of $£ 150,000$.

According to the conference office at Southampton, the organizing secretary, Professor Peter Ucko, professor of archaeology at Southampton, "used every possible argument" earlier in the summer to persuade the local objectors to abandon their positions. He said this week that he had commended individual participation in the congress and the need for free speech among academics.

The design of the ban of scientists from South Africa is such as to exclude all those who work at South African institutions, or who are paid by South African organizations. (South Africans working outside the republic are not excluded.) The point is especially ironical as it affects Tobias, who was scheduled to give one of the plenary talks at next year's symposium, and who has a British passport.

IUPPS is not affiliated to the International Council of Scientific Unions (ICSU) but to the International Council of Philosophy and Human Sciences (CIPSH), which is itself a dependant of UNESCO. As a further irony, the governing council of IUPPS includes two South African scientists, Tobias and R.J. Mason (also from Witwatersrand). No doubt these two will have more to say as and when the occasion arises.

\section{of GMT}

funds have been allowed. The result is that observations with important statistical weight will not be available for transmission to Paris when the clocks fail, as they are expected to do in the months ahead.

This does not mean that Greenwich will lack a standard of time, for it is hoped to operate three caesium clocks as part of the laser ranging programme mounted at Greenwich, for which continuing support is being negotiated by SERC. But the phrase Greenwich Mean Time will thereafter need qualification.

A senior member of the observatory said earlier this week that the prospect that Britain might cease to contribute towards the international standards of time had arisen because SERC is required to make decisions about the disposition of its budget within the strict context of its terms of reference.

Other government departments had declined to take over the responsibility, he said, on the grounds that the provision of a time service rested firmly with SERC as the manager of the observatory. The astronomer said that the consequence was that projects considered "desirable nationally" could be forgotten.
John Maddox 